\title{
Defining Parameters: Aboriginal Rights, Treaty Rights, and The SPARROW Justificatory Test
}

\author{
LEONARD I. ROTMAN ${ }^{*}$
}

In the case of R. v. Sparrow, the Supreme Court of Canada created a justificatory scheme for federal legislation that had the potential to derogate from the rights of the Aboriginal peoples that are protected by s. 35(I) of the Constitution Act, 1982. Since that time, the Sparrow test has been applied to both Aboriginal and treaty rights. The author suggests that the straightforward application of the Sparrow test to treaty rights is inappropriate because of the significant distinctions between Aboriginal and treaty rights. Where there is a need to balance treaty rights with competing rights, any justificatory standard to be applied ought to be consistent with the consensual basis of CrownNative treaties.
Dans R. c. Sparrrow, la Cour suprême du Canada a créé une norme justificative qui permet en substance qu'un texte législatif fédéral porte atteinte aux droits autochtones protégés par le par. 35(I) de la Loi constitutionnelle de 1982. Depuis lors, ce critère a été appliqué à la fois aux droits ancestraux et aux droits issus de traités. L'auteur soutient que l'application directe du critère Sparrow aux droits issus de traités est inappropriée, compte tenu des distinctions importantes existant entre ces deux catégories de droits. Quand il s'agit de mettre en regard des droits issus de traités et des droits contradictoires, tout critère de justification invoqué devrait se conformer au principe consensuel des traités entre la Couronne et les peuples autochtones.

\section{TABLE OF CoNTENTS}

I. INTRODUCTION . . . . . . . . . . . . . . . . . . 149

II. THE SPARROW DECISION AND THE SPARROW

JUSTIFICATORY TEST . . . . . . . . . . . . . . . . . . . . 150

III. CASES ON THE APPLICATION OF THE SPARROW TEST

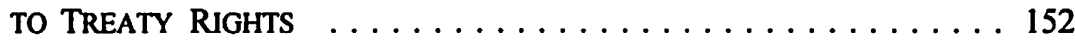

IV. ABORIGINAL RIGHTS AND TREATY RIGHTS $\ldots \ldots \ldots \ldots \ldots \ldots 156$

V. THE IMPLICATIONS OF THE SPARROW DECISION $\ldots \ldots \ldots \ldots \ldots 161$

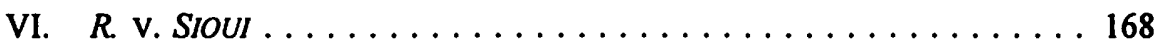

VII. CONCLUSION $\ldots \ldots \ldots \ldots \ldots \ldots \ldots \ldots \ldots \ldots \ldots \ldots \ldots$

\section{INTRODUCTION}

In the landmark case of $R$. v. Sparrow, ${ }^{1}$ the Supreme Court of Canada instituted a justificatory scheme for legislation that infringed upon Aboriginal rights. In the recent Supreme Court decision in $R$. v. Cote $e^{2}$ Chief Justice Antonio Lamer declared that the Sparrow justificatory test applied equally to treaty rights. ${ }^{3}$ The Chief Justice premised his findings on the Supreme Court's earlier decision in $R$. v. Badger, where both the majority and minority judgments discussed the application of the Sparrow test to treaty rights. ${ }^{4}$ Notwithstanding the definitiveness of Chief Justice Lamer's findings in Coté,

Assistant Professor, Faculty of Law, University of Alberta. I wish to thank Cathy Bell and David Schneiderman for their helpful comments on earlier drafts of this article.

(1990), 70 D.L.R. (4th) 385 (S.C.C.).

[1996] 4 C.N.L.R. 26 (S.C.C.).

Ibid. at 40-41 (para. 33), 55-56 (para. 74).

[1996] 2 C.N.L.R. 77 (S.C.C.). 
this article suggests that applying the Sparrow test to treaty rights - although not prohibited by the Sparrow decision - is inappropriate because of the significant distinctions between Aboriginal and treaty rights.

While this article will assert that the Sparrow test ought not be applied to treaty rights, it does not propose to comment on the appropriateness of the Sparrow justificatory standard to Aboriginal rights. Whether the Sparrow test is or is not an appropriate response to the balancing of Aboriginal rights versus governmental legislative initiatives - especially in light of the Supreme Court of Canada's recent commentary on that test in $R$. v. Gladstone ${ }^{5}$ - is a matter for another day. Instead, the article will focus on the reasons provided in the case law for the application of the Sparrow justificatory standard to treaty rights. It will also examine the differences between Aboriginal and treaty rights. It will then propose a different justificatory standard for legislative infringements of treaty rights that accounts for the sui generis nature of the treaty making process between the Crown and the Aboriginal peoples in Canada.

\section{The SPARRow Decision AND THE SPARRow Justificatory TeST}

The Sparrow case was concerned with the traditional rights of Aboriginal peoples to fish and whether those rights fell under the regulatory scheme established by federal fishing legislation. Framed more broadly, the primary question before the Court in Sparrow was whether constitutionally-protected Aboriginal rights could be limited by legislation. The unanimous judgment of the Supreme Court of Canada held that Aboriginal rights could be limited by governmental legislative initiatives, but only under certain circumstances. The circumstances set out by the Court comprise what is now known as the Sparrow justificatory test.

The Sparrow test allowed for the limitation of Aboriginal rights only by valid legislative objectives. While the conservation and management of fisheries was held to constitute a valid objective, infringements of Aboriginal rights on the basis of "public interest" was held to be so vague as to provide no meaningful guidance and so broad as to be untenable as a test for justifying limitations on constitutional rights. ${ }^{6}$ Furthermore, the range of permissible objectives was restricted to those found to be "compelling and substantial." The legislation could not have an underlying unconstitutional objective and had to be "absolutely necessary to accomplish the required limitation." ${ }^{\prime 8}$ In addition, any limitation had to be consistent with the Crown's

[1996] 4 C.N.L.R. 65 (S.C.C.).

Supra note 1 at 412 . It should be noted, however, that the recent application of the Sparrow test in Gladstone, supra note 5, appears to sanction "public interest" as a legitimate basis for restricting Aboriginal rights. See the discussion of Gladstone in K. McNeil, "How Can Infringements of the Constitutional Rights of Aboriginal Peoples be Justified?" (1997) 8 Constitutional Forum 33.

$7 \quad$ Supra note 1 at 412 .

- Ibid. at 417-18. In other words, it is only where there is no other viable option to the infringement of s. 35(1) rights that a legislative objective, having passed the requirements set out by the Sparrow test, may be upheld by the courts. Even where legislation is upheld in this way, there exists an obligation to consult with the Aboriginal peoples affected with regard to the legislative 
fiduciary duty to the Aboriginal peoples. ${ }^{9}$ This entailed that, in appropriate circumstances, the Crown was obliged to: infringe Aboriginal rights as little as possible to effect the desired result; ${ }^{10}$ consult with the Aboriginal peoples;" and provide compensation. $^{12}$

The implementation of the justificatory test for federal legislative initiatives in Sparrow came about as a result of combining the federal Crown's legislative powers over "Indians, and Lands reserved for the Indians" in s. 91(24) of the Constitution Act, 1867 and its fiduciary responsibility to Aboriginal peoples enshrined in s. 35(1). ${ }^{13}$ Before the Supreme Court's decision in Sparrow, there had been no express limitation of the federal Crown's ability to legislate in respect of "Indians, and Lands reserved for the Indians" pursuant to its s. 91(24) power. The Sparrow court found that the Crown's obligation to live up to a high standard of conduct - as specified in Nowegijick $\mathbf{v}$. $R^{14}$ and in Guerin v. $R^{15}$ and enshrined within s. $35(1)$ - entailed the imposition of reasonable limits upon the Crown's exercise of its legislative powers over Aboriginal peoples. Consequently, any legislative measures that adversely affect Aboriginal rights must be consistent with the terms of s. 35(1). This requires "sensitivity to and respect for the rights of Aboriginal peoples on behalf of the government, courts and indeed all Canadians." 16

The test established in Sparrow was discussed in relation to Aboriginal rights as a result of the matter in issue before the Court. Soon after the Sparrow decision, the justificatory test that the Supreme Court had established began to be applied to situations involving both Aboriginal and treaty rights. Insofar as the Court in Sparrow had not limited the application of its justificatory test to Aboriginal rights, this process appeared to be a logical extension of the Sparrow judgment. Indeed, the Supreme Court had stated in Sparrow that the application of its justificatory standard was to be implemented on a case-by-case basis because of the generality of s. 35(1) of the Constitution Act, $1982^{17}$ and the "complexities of Aboriginal history, society and rights." However, as the limited reasoning provided in subsequent cases indicates, the application of the Sparrow test to treaty rights was presumed as a matter of fact

initiative to be implemented.

Jbid. at 413.

Ibid. at 416.

Ibid. at 417.

Ibid. at 416-17.

lbid. at 409. For greater discussion about the Crown's fiduciary duty to Aboriginal peoples, see L.I. Rotman, Parallel Paths: Fiduciary Doctrine and the Crown-Native Relationship in Canada (Toronto: University of Toronto Press, 1996) [hereinafter "Parallel Paths"]; P.W. Hutchins, D. Schulze \& C. Hilling, "When Do Fiduciary Obligations to Aboriginal People Arise?" (1995) 59 Sask. L. Rev. 97; L.I. Rotman, "Provincial Fiduciary Obligations to First Nations: The Nexus Between Governmental Power and Responsibility" (1994) 32 Osgoode Hall L.J. 735.

(1983), 144 D.L.R. (3d) 193 (S.C.C.).

(1984), 13 D.L.R. (4th) 321 (S.C.C.).

Supra note 1 at 417.

Enacted as Schedule B to the Canada Act, 1982 (U.K.), 1982, c. 11.

Supra note 1 at 410. 
rather than having been reasoned from the nature of treaty versus Aboriginal rights or the dictum of the Supreme Court in Sparrow.

\section{Cases on the application of the SPARROW TEST TO TREATY RIGHTS}

After the Supreme Court'sjudgment in Sparrow was released, provincial jurisdictions began applying the Sparrow justificatory test indiscriminately to situations involving both Aboriginal and treaty rights. ${ }^{19}$ The precedent for this turn of events had been set prior to the Supreme Court of Canada's decision in Sparrow. In $R$. v. Agawa, which had been released after the British Columbia Court of Appeal's judgment in Sparrow, the court held that the principles applied by the British Columbia Court of Appeal - which foreshadowed the test instituted by the Supreme Court of Canada - applied equally to both Aboriginal and treaty rights. ${ }^{20}$

A closer examination of some of the cases in which the Sparrow justificatory test has been used for Aboriginal and treaty rights provides little guidance as to why that test ought to be applied equally to both forms of rights. It appears as though the significant distinction between Aboriginal and treaty rights was not given its proper due in those judgments. For example, in $R$. v. Bombay, Austin J.A. dealt with the issue in the following, cursory manner:

The Sparrow case dealt with the Aboriginal rights. The language of the decision of the Supreme Court of Canada in that case, however, is equally applicable to treaty rights. In $R$. v. Joseph, [1990] 4 C.N.L.R. 59 (B.C.S.C.) Murphy J. held that the framework provided by the Supreme Court in Sparrow "applies also to treaty rights." I agree."1

Later, in $R$ v. Fox, the Ontario Court of Appeal again affirmed the application of the Sparrow justificatory test to treaty rights. It simply held that: "In $R$. v. Sparrow, supra, the Supreme Court of Canada set out the framework analysis for assessing the constitutionality of legislation affecting treaty and Aboriginal rights recognized and affirmed under s. 35(1)."22

It may be seen that there was no consideration given in the Bombay and Fox judgments to the significant distinction between Aboriginal and treaty rights. Instead, it appears as though the placing together of those rights in s. 35(1) was solely responsible for the Sparrow test's application to treaty rights, not because of any reasoned analysis of why treaty rights should be treated like Aboriginal rights with respect to their limitation by governmental legislative initiatives. 
In addition to these judicial decisions on the application of the Sparrow test, some academic commentators assumed that the Sparrow test would or should apply equally to Aboriginal and treaty rights. As Macklem explained: "Though Sparrow strictly speaking was not a case which involved the assertion of treaty rights, there is no reason why a similar approach might not be taken with respect to laws which regulate or extinguish treaty rights." ${ }^{.23}$ Wildsmith made a comparable assertion:

The Supreme Court has not determined that treaty rights should be analyzed in the same way as Aboriginal rights, but a likely outcome is that treaty rights will not be seen as absolute and will be found subject to infringement by governments in sufficiently compelling cases. ${ }^{24}$

Meanwhile, McNeil stated that while the Sparrow case did not explicitly deal with treaty rights, "as both Aboriginal and treaty rights receive the same protection in s. $35(1)$, their constitutional status should be the same."2s

It was not until the Supreme Court of Canada's recent decision in Badger that that court had an opportunity to comment on the application of the Sparrow test to treaty rights. In Badger, Cory J.'s majority decision concluded that although the Sparrow decision dealt with Aboriginal rights, the test formulated therein applied equally to treaty rights "in most cases." ${ }^{26}$ Why the application of the Sparrow test to treaty rights was qualified to render it applicable only to "most cases," as opposed to all cases, was not discussed in the judgment.

In finding the Sparrow test to be applicable to treaty rights in Badger, Cory J. expressly noted the distinction between Aboriginal and treaty rights. As he explained:

There is no doubt that Aboriginal and treaty rights differ in both origin and structure. Aboriginal rights flow from the customs and traditions of the Native peoples. To paraphrase the words of Judson J. in Calder ... they embody the right of native people to continue living as their forefathers lived. Treaty rights, on the other hand, are those contained in official agreements between the Crown and the Native peoples. Treaties are analogous to contracts, albeit of a very solemn and special, public nature. They

P. Macklem, "First Nations Self-Government and the Borders of the Canadian Legal Imagination" (1991) 36 McGill L.J. 382 at 436.

B.H. Wildsmith, "Treaty Responsibilities: A Co-Relational Model" (1992) U.B.C. L. Rev. Special Edition on Aboriginal Justice 324.

K. McNeil, "Envisaging Constitutional Space for Aboriginal Governments" (1993) 19 Queen's L.J. 95 at 101 (note 20). It should be noted, however, that McNeil altered his position in a subsequent publication. See R. Dupuis \& K. McNeil, Canada's Fiduciary Obligations to Aboriginal Peoples in the Context of Accession to Sovereignty by Quebec, Volume II: Domestic Dimensions (Ottawa: Minister of Supply and Services Canada, 1995) at 45:

It can be argued, however, that infringements of treaty rights cannot be justified by the Sparrow test because violation of those solemn agreements directly involves the honour of the Crown, which the Supreme Court in Sparrow identified as a "guiding interpretive principle" where dealings with Aboriginal peoples are concerned. test to the situation before the court by Sopinka J., ibid. Despite this opposition, Sopinka J. did find that the principles underlying the Sparrow test, though not the test itself, were applicable to the facts in Badger. 
create enforceable obligations based on the mutual consent of the parties. It follows that the scope of treaty rights will be determined by their wording, which must be interpreted in accordance with the principles enunciated by this Court. ${ }^{27}$

Cory J. also found that there were "significant aspects of similarity" between Aboriginal rights and treaty rights. Specifically, he held that:

\begin{abstract}
Although treaty rights are the result of mutual agreement, they, like Aboriginal rights, may be unilaterally abridged. See Horseman, supra, at p. 936; R. v. Sikyea, [1964] 2 C.C.C. 325 (N.W.T.C.A.), at p. 330,642; and Moosehunter, supra, at p. 293. It follows that limitations on treaty rights, like breaches of Aboriginal rights, should be justified.
\end{abstract}

In addition, both Aboriginal and treaty rights possess in common a unique, sui generis nature.... In each case, the honour of the Crown is engaged through its relationship with the Native peoples. ${ }^{23}$

On the basis of these similarities, as well as the wording of s. 35(1) - which he found "supports a common approach to infringements of Aboriginal and treaty rights"29 Cory J. held that the Sparrow test was applicable to the treaty situation in Badger.

Cory J.'s consideration of Aboriginal and treaty rights in Badger makes it appear that his conclusion rests upon the same premise as that seen in Bombay and Fox - namely the placing together of Aboriginal and treaty rights in s. 35(1). Despite offering a cursory discussion of the nature of Aboriginal and treaty rights, Cory J. provides no additional reasoning beyond that offered in Bombay and Fox on which to found his conclusion. In any event, it would appear that Cory J. did not want his judgment to be understood as an authoritative proposition that the Sparrow test automatically applies to potential legislative infringement of both Aboriginal and treaty rights. Just as he had stated earlier in his judgment that the Sparrow test applies equally to treaty rights "in most cases," he prefaced his conclusions by stating that, in justifying legislative infringements of treaty rights, "the recognized principles to be considered and applied in justification should generally be those set out in Sparrow." that the principles established in Sparrow were not exhaustive, he explained that they "may serve as a rough guide when considering the infringement of treaty rights." From the tone of his judgment, as well as its self-imposed qualifications, Cory J.'s decision in Badger can hardly be understood as a hearty endorsement of the Sparrow test's application to treaty rights.

In the Supreme Court's most recent consideration of the Sparrow test's use vis-à-vis treaty rights in Coté, Lamer C.J.C. also found that the Sparrow test was applicable. As he explained:

\footnotetext{
Ibid. at 105 (para. 76).

Ibid. at 105-106 (paras. 77, 78).

Ibid. at 106 (para. 79).

Ibid. at 107 (para. 85) [emphasis added].

lbid. at 108 (para. 85).
} 
As a general rule, where a claimant challenges the application of a federal regulation under s.35(1), the characterization of the right alternatively as an Aboriginal right or as a treaty right will not be of any consequence once the existence of the right is established, as the Sparrow test for infringement and justification applies with the same force and the same considerations to both species of constitutional rights: $R$. v. Badger, [1996] 1 S.C.R. 771, at paras. 37, 77 and 78 and $79 .^{32}$

The Chief Justice later reaffirmed this position in making the following statement:

In Sparrow, the Court set out the applicable framework for identifying the infringment of an Aboriginal right or treaty right under s.35(1) of the Constitution Act, 1982. It should be noted that the test in Sparrow was originally elucidated in the context of a federal regulation which allegedly infringed an Aboriginal right. The majority of recent cases which have subsequently invoked the Sparrow framework have similarly done so against the backdrop of a federal statute or regulation.... But it is quite clear that the Sparrow test applies where a provincial law has infringed an Aboriginal or treaty right in a manner which cannot be justified.... The text and purpose of s.35(1) do not distinguish between federal and provincial laws which restrict Aboriginal or treaty rights, and they should both be subject to the same standard of constitutional scrutiny. ${ }^{33}$

Although the Chief Justice's focus in this latter statement is on the distinction between federal and provincial legislation, he once again affirmed, without reasons, the application of the Sparrow test to Aboriginal and treaty rights. His statement that S. 35(1) does not distinguish between federal and provincial legislation can be contrasted with the fact that s. 35(1) does distinguish between Aboriginal and treaty rights.

An interesting aspect of the Chief Justice's decision in Coté is that it appears to be far more conclusive on the question of the Sparrow test's application to treaty rights than the Badger judgment upon which it rests. Although he prefaces his application of the Sparrow test to treaty rights by stating that his finding is a "general rule," the language he uses is unequivocal - "the characterization of the right alternatively as an Aboriginal right or as a treaty right will not be of any consequence once the existence of the right is established." ${ }^{34}$ Once again, as in the cases discussed previously, the Chief Justice failed to provide any rationale for why the Sparrow test ought to apply to treaty rights.

The failure of case law to explain why the Sparrow test ought to apply to treaty rights posits either of two scenarios: that the application of the Sparrow test to treaty rights is so obvious as to negate the need for explanation, or that there is no informed basis upon which to apply to Sparrow test to treaty rights. It is suggested that the latter is the more accurate statement. There are significant distinctions between Aboriginal and treaty rights which militate against using the same justificatory standard for the limitation of those rights. The following section will examine some of these distinctions.

$34 \quad$ Ibid. at 40 (para. 33). 


\section{AbORiginal RightS and TREATY RightS}

The distinction between Aboriginal and treaty rights is an important one. That the protection of Aboriginal peoples' rights in s. 35(1) specifically distinguishes between Aboriginal and treaty rights illustrates the distinctiveness of those forms of rights. This distinctiveness ought to be reflected in the standard that applies to legislative initiatives that may limit existing treaty rights from that applied to legislation affecting Aboriginal rights. The standard for limiting treaty rights should reflect an awareness of the special nature of treaty rights and what distinguishes them from Aboriginal rights. In championing the creation of a standard for limiting treaty rights that is distinct from the test created in Sparrow I do not wish to suggest that treaty rights may not be infringed upon by legislation whereas Aboriginal rights may be. This issue will be considered in more detail later.

Aboriginal rights and treaty rights are often discussed together, without distinction, in Canadian Aboriginal rights jurisprudence. In fact, confusion sometimes arises over the indiscriminate use of the phrase "Aboriginal rights" to describe what are, in fact, separate entities. The term "Aboriginal rights jurisprudence," for example, is used generically to describe case law relating both to Aboriginal and treaty rights. The rights contemplated by the phrase "Aboriginal rights" are, more often than not, intended to include the totality of the rights belonging to the Aboriginal peoples. Moreover, s. 35 of the Constitution Act, 1982 neither separates the protection of Aboriginal and treaty rights in subsection (1) nor the qualification imposed upon those rights by subsection (4). While the grouping together of Aboriginal and treaty rights may be appropriate in some situations, it is not appropriate where it ignores the distinctions between them that justify their independent existence.

The most significant distinction between Aboriginal rights and treaty rights is their origins. Aboriginal rights are derived from Aboriginal customary laws and traditions. Accordingly, they are not dependent upon recognition or affirmation by the common law for their existence. As Hall J. explained in Calder v. Attorney General of British Columbia in relation to Aboriginal title, Aboriginal rights are not dependent upon treaty, executive order, or legislative enactment. ${ }^{35}$ This conclusion was premised on two American decisions which held that governmental recognition of Aboriginal land rights was not necessary for those rights to exist. ${ }^{36}$ This element of the Calder

(1973), 34 D.L.R. (3d) 145 at 200 (S.C.C.). Note also the judgment of Judson J., ibid. at 156: Although I think it is clear that Indian title in British Columbia cannot owe its origin to the Proclamation of 1763 , the fact is that when the settlers came, the Indians were there, organized in societies and occupying the land as their forefathers had done for centuries. This is what Indian title means.... treaty, statute, or other formal governmental action"; Cramer v. United States (1923), 261 U.S. 219 at 229: "The fact that such right of occupancy finds no recognition in any statute or other formal governmental action is not conclusive." 
decision was subsequently affirmed by the Supreme Court of Canada in Guerin, ${ }^{37}$ and, most recently, in Coté. ${ }^{38}$ The independent existence of Aboriginal rights has also been explained by the Manitoba Aboriginal Justice Inquiry in the following manner:

To the extent that Aboriginal rights of Aboriginal people have been confirmed in other Canadian or British laws, it has another form of recognition, but the state of the law in Canada, as we understand it, is that Aboriginal people and their rights did not depend upon non-Aboriginal recognition in order to exist. ${ }^{39}$

Treaty rights, meanwhile, are rights that are enshrined within the terms of various treaties entered into between the Crown and Aboriginal nations. Treaties were a fundamental part of early European-Aboriginal diplomacy in North America. When the first formal treaty between Britain and the Aboriginal peoples of North America - the Treaty of Albany - was signed in 1664, British-Aboriginal alliances had already existed on a less formal basis for quite some time. Treaties between European and Aboriginal nations secured alliances and consolidated relations between diverse groups. From the Europeans' perspective, treaties provided substantial economic, military, and political benefits. For the Aboriginal peoples, treaties yielded these same economic, military, and political alliances, yet also provided a basis for asserting their rights in the wake of European intrusions on their lands and interference with their ways of life. ${ }^{40}$

The mutuality of the treaty-making process between Britain and the Aboriginal peoples is illustrated by its development as a combination of British and Aboriginal practices. These treaties were characterized by the use of written, parchment copies, the recording of agreements on wampum belts, ${ }^{41}$ and the exchange of presents. The use of formally written treaties on parchment was a practice that Britain had reserved for its

Supra note 15. See also Hamlet of Baker Lake v. Canada (Minister of Indian Affairs and Northern Development) (1979), 107 D.L.R. (3d) 513 at 541 (F.C.T.D.).

Supra note 2. In Coté, Lamer C.J.C. stated, at 48 (para. 52), that:

[T] he fact that a particular practice, custom or tradition continued, in an unextinguished manner, following the arrival of Europeans but in the absence of the formal gloss of legal recognition ... should not undermine the constitutional protection accorded to Aboriginal peoples. Section 35(1) would fail to achieve its noble purpose of preserving the integral and defining features of distinctive Aboriginal societies if it only protected those defining features which were fortunate enough to have received the legal recognition and approval of European colonizers. Aboriginal People, vol. 1 (Winnipeg: Queen's Printer, 1991) (Commissioners: A.C. Hamilton \& C.M. Sinclair) at 261.

40 See J.Y. Henderson, "Interpreting Sui Generis Treaties" (1997) 36 Alta. L. Rev. 46 at 51.

41 Wampum belts are made from beads fashioned out of shells, which were pierced and sewn into patterns on animal hides. See Chief J.M. Matchewan, "Mitchikanibikonginik Algonquins of Barriere Lake: Our Long Battle to Create a Sustainable Future" in B. Richardson, ed., Drumbeat: Anger and Renewal in Indian Country (Toronto: Summerhill Press, 1993) 141; D. Johnston, "The Quest of the Six Nations Confederacy for Self-Determination" (1986) 44 U.T. Fac. L. Rev. 1 at 9; R.A. Williams, Jr., "The Algebra of Federal Indian Law: The Hard Trail of Decolonization and Americanizing the White Man's Indian Jurisprudence" (1986) Wisc. L. Rev. 219 at 291; W.R. Jacobs, Dispossessing the American Indian: Indians and Whites on the Colonial Frontier (New York: Charles Scribner's Sons, 1972) at 41-49. 
relations with independent, sovereign powers. Meanwhile, the Aboriginals' representation of agreements on belts of wampum, which were highly valuable and required great skill to make, demonstrated the sanctity with which they viewed their alliances with Britain. ${ }^{42}$ The use of formal agreements by Aboriginal peoples was also a practice that had been used by many of them prior to contact with the Europeans. ${ }^{43}$

The rights guaranteed to Aboriginal peoples in treaties with the Crown are the result of consensual negotiations between the Crown and Aboriginal peoples. Each side obtained valuable consideration from the other, but only after giving up something equally desired. This may have been tangibles - such as rights to land, goods, or money - or intangibles, including guarantees of rights, or promises of peace, protection, or non-interference with another's affairs. As negotiated rights, treaty rights may be comprised of any rights agreed to by the parties involved. This may include pre-existing Aboriginal rights which have been incorporated into a treaty, rights obtained from the Crown as a part of the treaty making process which did not exist previously, or both. For instance, an existing Aboriginal right to hunt may have been explicitly incorporated into the term of a treaty to ensure that the Crown both knew of and respected the continued existence of that right. Examples of rights included in a treaty that did not exist previously include the establishment of a reserve, the payment of money or an annuity, specified quantities of grain, blankets, horses, or other implements, and the right to a medicine chest or schooling. ${ }^{44}$

Where Aboriginal rights are incorporated into a treaty as treaty rights, the Aboriginal rights do not automatically disappear nor are they superseded by the treaty rights. Treaties that protect Aboriginal rights in the manner in which they had been exercised until that point protect those rights, as treaty rights, in their full form. However, new rights created for Aboriginal peoples in treaties are no more expansive than their interpretation within the context of the treaty itself and the events surrounding their negotiation. This interpretation is subject, of course, to the canons of treaty interpretation that are a fundamental aspect of treaty jurisprudence. These canons hold that treaties should be given a large, liberal, and generous interpretation in favour of the Aboriginal peoples; ambiguities in treaties are to be resolved in favour of the Aboriginals; treaties ought to be construed as the Aboriginal signatories understood them; treaties are to be interpreted in a flexible manner and extrinsic evidence may be

See Jacobs, ibid. at 42.

See Union of Nova Scotia Indians, The Mi'kmaq Treaty Handbook (Sydney \& Truro, N.S.: Native Communications Society of Nova Scotia, 1987) Preface, at i:

Well before the arrival of Europeans, formal agreements equivalent to treaties were negotiated between sovereign nations of North America. The meaning and effect of these arrangements were not limited by a few words on paper as are present-day business contracts. Rather, these treaties were living and evolving relationships among various indigenous nations. Like the members of a family, representatives of the nations that had entered into a treaty met from time to time to exchange gifts, forgive one another and renew their friendship. We, the Mi'kmaq, related to Europeans the same way.

Many of these rights were used, to varying degrees and extents, throughout the history of the treaty-making process between the Crown and Aboriginal peoples. 
used in examining Aboriginal treaties. ${ }^{45}$ Further, in interpreting treaties, it is necessary to account for both Aboriginal and Crown perspectives on the meaning of the agreements.

The incorporation of Aboriginal hunting and fishing rights, for example, into the terms of a treaty does not extinguish those rights or render them incapable of enforcement. Rather, it provides those rights with dual protection - under the systems or traditions from which they emanate as well as under the treaties themselves. As Dickson C.J.C. explained in Simon v. $R$ :

[T]he treaty, by providing that the Micmac should not be hindered from but should have free liberty of hunting and fishing as usual, constitutes a positive source of protection against infringements on hunting rights. The fact that the right to hunt already existed at the time the treaty was entered into by virtue of the Micmac's general Aboriginal right to hunt does not negate or minimize the significance of the protection of hunting rights expressly included in the treaty. ${ }^{45}$

The distinction between Aboriginal rights and treaty rights ought not be ignored, even in instances where Aboriginal rights have been protected and incorporated into the terms of treaties. Since Aboriginal rights are sui generis ${ }^{47}$ and not dependent upon common law recognition or affirmation, they are not to be defined exclusively by common law methods of analysis. Instead, they should be viewed in light of Aboriginal understandings and usage, which are then balanced with common law notions in accordance with their sui generis nature. ${ }^{48}$ As the Royal Commission on Aboriginal Peoples explained in Partners in Confederation, Aboriginal rights law is not just common law- or Aboriginal law-oriented, but draws upon both systems:

The doctrine of Aboriginal rights is common law in the sense that it is not the product of statutory or constitutional provisions and does not depend on such provisions for its legal force. Rather, it is based on the original rights of Aboriginal nations, as these were recognized in the custom generated by relations between these nations and incoming French and English settlers from the seventeenth century onward. This overarching body of fundamental law bridges the gap between Aboriginal groups and the general community and regulates the interaction between their legal and governmental systems, permitting them to operate harmoniously, each within its proper sphere. The doctrine is neither entirely

For more detailed discussion of these canons of treaty interpretation and why they exist, see L.I. Rotman, "Taking Aim at the Canons of Treaty Interpretation in Canadian Aboriginal Rights Jurisprudence" (1997) 46 U.N.B.L.J. 11. (1984), 24 D.L.R. (4th) 390 at 402 (S.C.C.); see also R v. Denny (1990), 94 N.S.R. (2d) 253 (S.C.A.D.).

47 Meaning "of its own kind or class." See Black's Law Dictionary, 5th ed. (St. Paul, Minn.: West, 1979) at 1286.

43 This balancing of Aboriginal and common law notions of Aboriginal rights is due to the realities of contact and the balancing of competing rights and interests in Canadian society that forms the basis of the Supreme Court of Canada's justificatory test in Sparrow, supra note 1. For further discussion of the balancing of Aboriginal and common law understandings of Aboriginal rights, see J. Borrows \& L.I. Rotman, "The Sui Generis Nature of Aboriginal Rights: Does It Make A Difference?" (1997) 36 Alta. L. Rev. 9. 
Aboriginal nor entirely European in origin but draws upon the practices and conceptions of all parties to the relationship, as these were modified and adapted in the course of contact. ${ }^{49}$

In addition to having greater focus upon Aboriginal understandings and definitions of the nature of Aboriginal rights, the content of an Aboriginal right encompasses more than the described right itself. For example, an Aboriginal right includes those practices which are reasonably incidental to the right in question. ${ }^{50}$ Therefore, the emphasis upon Aboriginal understandings and definitions of Aboriginal rights provides those rights with the potential to be interpreted in a more expansive manner than treaty rights. ${ }^{51}$ As the Royal Commission on Aboriginal Peoples has noted in relation to land rights:

Aboriginal peoples tend to see their relationships to land in terms of an overarching collective responsibility to protect, nurture, and cherish the earth as the giver of life. Aboriginal rights with respect to ancestral territory are understood by Aboriginal peoples as particular expressions of this more general and fundamental responsibility to the earth.

Canadian law structures Aboriginal and non-Aboriginal relationships with respect to land by precepts that emphasize rights of use and enjoyment of land as property entitlements. Canadian law treats the Crown as possessing underlying title to all its territory. ${ }^{32}$

Royal Commission on Aboriginal Peoples, Partmers in Confederation: Aboriginal Peoples, Self-Government, and the Constitution (Ottawa: Minister of Supply and Services Canada, 1993) at 20 [hereinafter "Partmers in Confederation"]. See also B. Slattery, "Understanding Aboriginal Rights" (1987) 66 Can. Bar Rev. 727 at 744-45.

In Simon, supra note 46 at 403 the Court found that the treaty right to hunt included the ability of an Aboriginal person exercising the right to engage in "those activities reasonably incidental to the act of hunting itself, an example of which is travelling with the requisite hunting equipment to the hunting grounds." Similarly, in Saanichton Marina Ltd. v. Claxton (1989), 36 B.C.L.R. (2d) 79 (C.A.), the British Columbia Court of Appeal held that the Tsawout band's 1852 treaty right to "carry on our fisheries as formerly," included the protection of the place where the band exercised that right. This entitled the band to receive a permanent injunction to prohibit a proposed marina from further development, since the marina would disrupt the band's fishery protected under treaty. As the court explained:

[C]onstruction of the marina will derogate from the right of the Indians to carry on their fisheries as formerly in the area of Saanichton Bay protected by the treaty. To begin with it will limit and impede their right of access to an important area of the bay. Further they will not be able to carry on the important stationary crab fishery as formerly.... This development, while of only a small area of the bay, will have a harmful impact on the right of fishery granted to the Indians by the treaty (at 92).

It should be noted, however, that the Supreme Court of Canada's majority decision in $R$. v. Van der Peet, [1996] 4 C.N.L.R. 177 (S.C.C.) held that so-called "incidental rights" were not Aboriginal rights under s. 35(1). For a contrary argument, see L.I. Rotman, "Hunting for Answers in a Strange Kettle of Fish: Unilateralism, Patemalism and Fiduciary Rhetoric in Badget and Van der Peet" (1997) 8 Constitutional Forum 40.

st For example, Aboriginal land rights are inextricably linked with other rights, such as hunting, fishing, and trapping, as well as the right of self-government. Consequently, they are arguably broader than any land right (based upon common law conceptions of ownership) than may be presently obtained in negotiations with the Crown.

32 Treaty Making in the Spirit of Co-existence: An Alternative to Extinguishment (Ottawa: Ministo of Supply and Services Canada, 1995) at 2. 
The potential breadth of Aboriginal rights has yet to be fully explored by the common law. This state of affairs may change, however, upon further judicial examinations of s. $35(1)$ of the Constitution Act, 1982.

Insofar as treaty rights do not have an independent existence like Aboriginal rights, but arise by way of negotiated compacts between the Crown and Aboriginal peoples, they are to be understood differently than Aboriginal rights. The canons of treaty interpretation prevent treaty rights from being restricted to their literal description in the treaties by incorporating Aboriginal understandings of those rights. However, the use of Aboriginal understandings of treaty rights does not result in the same method of analysis used in the interpretation of Aboriginal rights. Instead of forming the primary basis of analysis under examinations of Aboriginal rights, Aboriginal understandings in the context of treaty rights must be weighed against the Crown's understandings. As the Supreme Court of Canada explained in $R$. v. Sioui, the common intention of the parties is what is sought in defining the terms of a treaty. ${ }^{53}$

This common intention must be arrived at through a contextual examination of the parties' goals and ambitions, their conduct previous to, during, and after the negotiation of the treaties, as well as what would be reasonable to conclude from the aforementioned in light of the relative positions and strengths of the parties during the periods in question. ${ }^{54}$ In striving towards this common intention, however, one must not look only for any overlap between Crown and Aboriginal perspectives. If, for example, one party adopts a broad understanding of a treaty and the other adopts a narrow understanding, the only point of overlap would be the narrow understanding.

As a result of the significant distinctions between Aboriginal and treaty rights described above, the two forms of rights ought not be treated as interchangeable. If they were generally interchangeable, there would have been no need to consider them separately within s. 35(1). Consequently, where a judgment about the interpretation or regulation of Aboriginal rights is made, that judgment should not be automatically used as a precedent for treaty rights and vice versa. This distinction becomes particularly relevant in light of the Coté decision and its adoption of the Sparrow test for the justification of legislative infringements of treaty rights.

\section{THE IMPLICATIONS OF THE SPARROW DECISION}

The Sparrow decision itself was unclear as to whether the justificatory test it created applies to both Aboriginal and treaty rights contained in s. 35(1). While the Sparrow case dealt only with Aboriginal rights, specifically the Aboriginal right to fish, it neither restricted the application of its justificatory test to those rights nor expanded the test's application to treaty rights. The court spoke generally about Aboriginal rights and s. 35(1) rights without limiting or defining the nature of the rights it was discussing: 
There is no explicit language in the provision [section 35(1)] that authorizes this court or any court to assess the legitimacy of any government legislation that restricts Aboriginal rights.... Rights that are recognized and affirmed are not absolute.... federal power must be reconciled with federal duty and the best way to achieve that reconciliation is to demand the justification of any governmental regulation that infringes upon or denies Aboriginal rights."s

It could be argued that limiting the Sparrow test's application to Aboriginal rights would improperly abridge the test's application. Similar arguments were made regarding the scope of the Crown's fiduciary duty following its entrenchment in the Guerin decision. ${ }^{56}$ However, there is a significant difference between the Guerin and Sparrow scenarios that demonstrates the necessity to read Guerin broadly and Sparrow narrowly.

In Guerin, the Supreme Court of Canada was faced with questions regarding the nature and extent of the federal Crown's obligations to the Musqueam band in leasing part of that band's reserve lands to a third party. ${ }^{57}$ The Court determined that a fiduciary relationship existed between the Crown and the band because of: the history of Crown-Native relations leading up to the Royal Proclamation of 1763; the nature of Aboriginal title; the relationship between the band and the Crown; and the surrender requirements contained within the Indian Act. ${ }^{58}$ The Court then found that the Crown had breached its duty to the band by failing to lease the land in accordance with terms specified by the band.

The Guerin case spoke specifically to the surrender of Aboriginal reserve lands to the federal Crown for lease purposes. Consequently, it was argued that the fiduciary obligation found in Guerin applied only to the federal Crown and only in the context of land surrenders. However, the limited scope of the Guerin decision was the result of the context in which it arose, not because of the narrowness of the Crown's obligations to Native peoples. There was no other compelling reason to restrict the Crown's fiduciary duty to the surrender of land for leasing purposes. Indeed, Dickson J., as he then was, expressly contextualized the limited scope of his examination of the Crown's fiduciary duty in the Guerin case by stating that the relevance of the Crown's fiduciary duty "in the present appeal ... is based on the requirement of a 'surrender'

ss $\quad$ Supra note 1 at 409.

so $\quad$ See, for example, Kruger v. R. (1985), 17 D.L.R. (4th) 591 (F.C.A.) per Heald J.A.; Blueberry River Indian Band and Doig River Indian Band v. Canada (Minister of Indian Affairs and Northern Development) (1987), 14 F.T.R. 161; Paul v. Canadian Pacific Ltd. (1989), 53 D.L.R. (4th) 487 (S.C.C.). The restrictive interpretation of Dickson C.J.C.'s judgment in Guerin is discussed in greater detail in Parallel Paths, supra note 13, c. 5.

37 Under the provisions of the federal Indian Act, R.S.C. 1985, c. 1-5, s. 37, Indian bands are prohibited from selling, leasing, or otherwise alienating title to their lands other than to the federal Crown, which may then sell or lease those lands to third parties. Surrenders may only be made to the federal Crown because of its exclusive jurisdiction over "Indians, and Lands reserved for the Indians," in s. 91(24) of the Constitution Act, 1867. For further discussion of the Indian Act's surrender requirements, see J. P. Salembier, "How Many Sheep Make a Flock? An Analysis of the Surrender Provisions of the Indian Act" [1992] 1 C.N.L.R. 14.

For greater discussion of the Guerin decision, see Parallel Paths, supra note 13, c. 5. 
before Indian land can be alienated." $59 \mathrm{Had}$ he wanted to indicate that the Crown only possessed fiduciary obligations to Native peoples within the context of the surrender of reserve lands, he would have specifically limited the Crown's obligations to that context. The Federal Court of Appeal's decision in Kruger v. $R .{ }^{60}$ which was released shortly after the Supreme Court of Canada's pronouncement in Guerin, affirmed this interpretation of the Guerin decision. ${ }^{61}$

The Sparrow decision ended the debate over the extent of the Crown's fiduciary duties to the Aboriginal peoples by determining that the Supreme Court's findings in Guerin encompassed relations between the Crown and Aboriginal peoples generally. The Court in Sparrow also found that the Crown's fiduciary obligations were entrenched in s. 35(1) of the Constitution Act, 1982, thereby rendering them of a more concrete nature than their status had been after Guerin. ${ }^{62}$ After Sparrow, not only did the Crown's fiduciary obligations to Aboriginal peoples exist at common law, but they were now a part of the Canadian constitution and "its strength as a promise to the Aboriginal peoples of Canada." ${ }^{63}$ Later, in Mitchell v. Peguis Indian Band, Chief Justice Dickson echoed the point made in Kruger when he explained that "On its facts, Guerin only dealt with the obligations of the federal Crown arising upon surrender of land by Indians."

While it may be seen that limiting the Guerin precedent to situations involving the surrender of reserve lands by Aboriginal bands to the Crown is improper, limiting the application of the Sparrow justificatory test to Aboriginal rights issues does not create a similar injustice. As discussed earlier, Aboriginal rights are inherent rights, whereas treaty rights may be obtained only through negotiation with the Crown. Therefore, it could be argued that, as solemn engagements resulting from mutual agreements between the Crown and Aboriginal peoples, treaties cannot be limited in the manner contemplated by the Sparrow test. As negotiated rights, treaty rights should not be susceptible to being arbitrarily or unilaterally derogated from by the Crown. Indeed, as negotiated rights, they may take any form which is agreed to by the parties (in a manner similar to arguments in favour of freedom of contract).

If one accepts the fact that rights existing in a democratic society cannot be absolute, treaty rights, like Aboriginal rights, should also be caught by some form of restriction. Yet, once again, the distinction between Aboriginal rights as inherent rights and treaty

Supra note 15 at 339. See also Dickson C.J.C.'s comments, ibid at 339, where he discussed the relevance of the Aboriginal interest in land to the Crown's fiduciary obligation: "[T] gives rise upon surrender to a distinctive fiduciary obligation on the part of the Crown to deal with the land for the benefit of the surrendering Indians." [Emphasis added.]

so Supra note 56.

61 Ibid. at 597, 646.

62 Supra note 1 at $406-408$.

63 Ibid. at 389. The Crown's fiduciary obligations to Aboriginal peoples is now understood to extend to a variety of situations: see Parallel Paths, supra note 13. Note also P. Macklem, "Aboriginal Rights and State Obligations" (1997) 36 Alta. L. Rev. 97, where the author discusses whether the Crown has a fiduciary obligation to provide economic or social benefitts to Aborignal peoples. (1990), 71 D.L.R. (4th) 193 at 209 (S.C.C.) [emphasis in orginal]. 
rights as negotiated rights comes into play. Even in situations where treaty rights are identical to existing Aboriginal rights, the solemn nature of the treaties and the mutuality with which they were negotiated and signed militates against enabling the Crown to limit treaty rights without the consent of the Aboriginal peoples affected.

Since Aboriginal rights are inherent and do not depend upon Crown recognition or affirmation, the Crown accepted them in their full form when it assumed its position of power in Canada. Under the Doctrine of Continuity, the Crown was deemed, under its own laws, to have explicitly accepted all local laws and pre-existing rights of the Aboriginal peoples that it did not explicitly nullify or supersede at the time of its "acquisition" or assertion of sovereignty. ${ }^{65}$ The same principles which underlie the Doctrine of Continuity would have allowed the Crown to eliminate pre-existing Aboriginal rights entirely through executive action, such as the passing of legislation or the issuing of a royal proclamation. Treaty rights, however, are quite different, since they are entirely the product of negotiations between the parties.

Since treaties are negotiated instruments which the Crown has pledged its honour to uphold, it would be unseemly to allow those negotiated rights to be unilaterally altered by Crown legislation. As Gwynne J. explained in St. Catherine's Milling and Lumber Co. v. The Queen:

Now it is to be observed, that the faith of Her Majesty is solemnly pledged to the faithful observance of this treaty, and the government of the Dominion of Canada is made the instrument by which the obligations contained in it, which are incurred by and on behalf of Her Majesty, are to be fulfilled. ${ }^{66}$

The Crown is under a fiduciary duty to uphold the integrity of treaty rights that it has guaranteed and protected under its name. The strict nature of the Crown's duty suggests that it be able to infringe upon treaty rights only under the most urgent of circumstances. On those occasions where it is able to derogate from its guarantee of treaty rights to Native peoples, the Crown must act in accordance with fiduciary obligations of the highest order. ${ }^{67}$

See Campbell v. Hall (1774), 1 Cowp. 204, 98 E.R. 1045 (K.B.); Re Southern Rhodesia, [1919] A.C. 211 at 233 (P.C.); Amodu Tijani v. Secretary, Southern Nigeria, [1921] 2 A.C. 399 at 407 (P.C.); Oyekan v. Adele, [1957] 2 All E.R. 785 at 788 (P.C.); B. Slattery, Ancestral Lands, Alien Laws: Judicial Perspectives on Aboriginal Title (Saskatoon: University of Saskatchewan Native Law Centre, 1983) at 10-11. St. Catherine's Milling and Lumber Co. v. The Queen (1887), 13 S.C.R. 577 at 671.

After the establishment of the Crown's fiduciary duty and its entrenchment in s. 35(1), the Crown may no longer be liable to fulfil its treaty obligations under the dictates of honour and good conscience, as suggested by McGillivray J.A. in R. v. Wesley, [1932] 4 D.L.R. 774 at 788 (Alta. C.A.) [hereinafter Wesley]:

Assuming as I do that our treaties with Indians are on no higher plane than other formal agreements yet this in no wise makes it less the duty and obligation of the Crown to carry out the promises contained in those treaties with the exactness which honour and good conscience dictate and it is not to be thought that the Crown has departed from those equitable principles which the Senate and the House of Commons declared in addressing Her Majesty in 1867, uniformly governed the British Crown in its dealings with the aborigines. 
If treaty rights are subject to alteration at the whim of the Crown, the solemn nature of the treaties in which they are contained is necessarily ignored, the Crown's fiduciary duty breached, and its honour tarnished. Judicial recognition of the solemn nature of treaties between the Crown and Aboriginal peoples has resulted in the promulgation of special canons of treaty interpretation that apply to the compacts between the Crown and Native peoples. The Supreme Court of Canada has demonstrated its recognition of the solemn nature of treaties when it held that treaty rights could only be deemed to have been extinguished by strict proof thereof and then only with the consent of the Aboriginal signatories. ${ }^{68}$

Holding Aboriginal treaty rights to be subject to regulation at the whim of the Crown belittles their importance and, more importantly, the austerity of the treaties themselves. It transforms the understanding of treaties as constitutional or quasi-constitutional documents into mere agreements with the Crown that are subordinate to the Crown's legislative prerogatives. ${ }^{69}$ This is clearly not the way that the Crown represented the nature of treaties to the Aboriginal peoples. The speech of Sir William Johnson, Superintendent-General of Indian Affairs, after the signing of a treaty with the Ohio Indians in $\mathbf{1 7 6 5}$ is indicative of the Crown's representations of the solemnity of treaties to the Aboriginal peoples:

Children the Shawanese, Delawares \& Mingos, You have now subscribed to the Treaty before me confirming the Articles signed by the Delawares before, the greatest part of which will equally concern you all.

It remains that I desire you will consider that what you have signed is a solemn thing, an Engagement between the English which will always appear against those who violate it, so that you must not compare it with any little transactions amongst yourselves, which are often soon forgotten. No, this can't be forgotten, it will remain upon record, \& your People shall have coppys of it for their private satisfaction.

Think seriously then of what you have done, repeat it often amongst yourselves, \& where any doubt or difference may happen to arise observe the Article by which you have engaged to come to me, or those sett over you by the King for an Explanation or to Obtain Justice. - If you act differently your Breach of Faith will be publickly known, \& you must expect nothing but ruin, but if on the contrary you take due notice of what has passed \& observe your engagements the King will esteem you, his Subjects will consider you as Friends, your Wives \& Children may rest in security, whilst you pursue your Hunting \& enjoy your own Trade. - Think of this, never Deny, Alter or Evade what you have now agreed to \& consider what I have now said as a proof of my Friendship for all Indians, who in gratitude to His Majesties forgiveness are resolved to lead peaceable lives \& never to disturb the Public Tranquillity. ${ }^{70}$ 930; Badger, supra note 4 at 92 (para. 41); on the latter point, see Sioui, supra note 53 at 456.

7 As reproduced in E.B. O'Callaghan, ed., Documents Relative to the Colonial History of the State of New York, vol. 7 (Albany: Weed, Parsons, 1853-61) at 756 [hereinafter "NYCD"] 
While the Sparrow test's requirement of consultation with the Aboriginal peoples affected by government legislative initiatives may serve to offset somewhat the Crown's unfettered ability to alter treaty rights, it does not lessen the blow to the solemnity of the treaties created by the application of the Sparrow test to treaty rights. Allowing the application of the Sparrow test to treaty rights blurs the distinction between Aboriginal and treaty rights and provides the latter with no greater protection than the former. This is particularly true where pre-existing Aboriginal rights, such as hunting, fishing, or trapping rights, were expressly included in the terms of treaties.

The purpose of including Aboriginal rights within the treaties, from the Aboriginals' perspective, was to have a greater measure of protection of those rights. That does not suggest that the Aboriginal peoples viewed those rights as subject to being trumped at will by the Crown without their inclusion in a treaty. The Aboriginals were aware, though, that their rights were being ignored and sought to include them in treaties so that there would be more concrete recognition of those rights. The Aboriginal peoples' desire to have their rights included in treaties demonstrates their expectation that the Crown would honour the terms of the treaties. Meanwhile, the recognition of Aboriginal rights in treaties was accompanied, at least from the Crown's perspective, by a recognition of settler rights or the sharing of Aboriginal resources.

Section 35(1)'s preservation of the distinction between Aboriginal and treaty rights serves the purpose of protecting all rights of the Aboriginal peoples that remained in existence on 17 April 1982. Therefore, s. 35(1) protects both the existing rights of Aboriginal peoples who were not parties to treaties or groups who had rights that were not included in the terms of treaties they were party to. With the equal protection of Aboriginal and treaty rights under s. 35(1), are those rights now to be considered interchangeable? If one is to remain faithful to the significant distinctions between Aboriginal and treaty rights, the answer clearly is no.

As a result of the distinctions between Aboriginal and treaty rights, and in the absence of any demonstrated reason why the Sparrow justificatory test ought to be applied equally to Aboriginal and treaty rights, the mechanical application of the Sparrow test to treaty rights indicated by the Cote decision is inappropriate. PostSparrow adoptions of the Sparrow test to treaty rights have not demonstrated why that test applies to treaty rights. For these reasons, it is suggested that the application of the Sparrow justificatory test to treaty rights is in need of clarification by the Supreme Court of Canada beyond the limited discussion in Badger and lack of discussion in Coté."

Questioning the Sparrow test's application to treaty rights is not intended to suggest that treaty rights are absolute whereas Aboriginal rights are not. As with Aboriginal rights, treaty rights also vie for space with competing rights. Consequently, they must be balanced, in some reasoned way, with those other rights. In providing an appropriate framework for this balancing act, it must be recognized that the breadth and extent of Aboriginal rights is dependent upon the practices of the Aboriginal peoples themselves, 
whereas treaty rights are dependent upon the extent of their recognition in the treaties, broadly construed. However, where certain rights exist as Aboriginal and treaty rights, as with Aboriginal rights replicated in the terms of a treaty, they benefit from both forms of protection. The reasonable balancing of competing rights neither entails the subjugation of treaty rights to those other rights, nor does it mean that treaty rights are to be viewed as any less solemn than the nature of the treaties indicates.

In Agawa, Blair J. held that treaty rights to hunt and fish, unlike treaty rights to land, must be viewed in light of contemporary realities. One of these realities, he explained, was resource conservation:

[I]t must be borne in mind that not all Indian treaty rights are absolute and immutable. While Indian property rights derived from treaties may remain virtually unqualified, hunting and fishing rights cannot be divorced from the realities of life in present-day Canada. Much has changed since the treaty was executed in 1850 . At that time, fish and game may have been regarded as limitless resources. They are no longer. ${ }^{2}$

While treaty rights to hunt, fish, and trap may exist in different circumstances in the present day than when the treaties were signed, the nature of the agreements made indicate that if the rights guaranteed under the treaties cannot be feasibly preserved in the form agreed to, they ought to be given some form of priority over competing rights that are not subject to similarly solemn recognition and protection by the Crown. In a similar vein, it is reasonable to hold that if treaty rights are to be read in a manner consistent with contemporary realities, as suggested in Agawa, that ought to apply equally to other treaty promises, such as the amount of Crown annual payments, annuities guaranteed under the treaties, or promises to provide schools or a medicine chest.

Where treaties promised money, schools, or a medicine chest, it is logical to suggest that, as constitutional documents, treaties ought to be read in an evolutionary way. The notion of the constitution as a "living tree" or document capable of evolution over time is well-entrenched in Canadian legal thought. ${ }^{73}$ Moreover, as the Supreme Court explicitly held in Simon, treaties should be "interpreted in a flexible way that is sensitive to the evolution of changes." ${ }^{74}$ Consequently, if money promised under treaties was intended to provide the Aboriginal signatories with a reasonable livelihood, then reason and justice should dictate that the amounts promised be increased to make

Agawa, supra note 20 at 121.

See, for example, Edwards v. Canada (A.G.), [1930] A.C. 124 at 136 (P.C.): "The British North America Act planted in Canada a living tree capable of growth and expansion within its natural limits"; Hunter v. Southam (1984), 11 D.L.R. (4th) 641 at 649 (S.C.C.) citing Edwards:

A constitution, ... is drafted with an eye to the future. Its function is to provide a continuing framework for the legitimate exercise of governmental power and, when joined by a Bill or a Charter of rights, for the unremitting protection of individual rights and liberties. Once enacted, its provisions cannot easily be repealed or amended. It must, therefore, be capable of growth and development over time to meet new social, political and historical realities often unimagined by its framers.

Supra note 46 at 403. 
them commensurate with contemporary costs and expenses. Similarly, if treaty promises of schools or a medicine chest were intended to provide education and health care in a manner that was appropriate to the time, then those promises should also be translatable, in a modern sense, to the building of schools and hospitals or medical clinics. $^{75}$

The solemn nature of treaties as representative of the agreements made between the Crown and Aboriginal peoples and their existence as negotiated compacts suggest that any attempt to abrogate the rights contained within them ought to be subject to a more onerous test than that applied to Aboriginal rights. As Wildsmith has stated:

The Sparrow principle emphasizing that the Crown must act honourably and in a manner consistent with its fiduciary/trust responsibilities is particularly onerous when regard is had to treaty rights. Breaking an express "solemn engagement" arrived at as a quid pro quo for promises on the part of the Aboriginal nations is prima facie dishonourable. ${ }^{76}$

For this reason, it is suggested that the rationale for understanding treaties established in Sioui, which focuses upon the common intention of the parties at the time a treaty was signed, ought to be used as the basis for justifying legislative abrogations of treaty rights rather than the test developed in Sparrow. The Sioui standard is far more consistent with the notion of treaties as negotiated compacts than the Sparrow test, which places its emphasis upon justifying unilateral legislative initiatives.

\section{R. v. SIOUI}

In the Sioui case, members of the Huron band of the Lorette Indian reserve had been charged with cutting down trees, camping, and making fires in unauthorized places in a public park in contravention of park regulations. The park was located within territory traditionally occupied by the band. The band members admitted committing the actions they were charged with, but claimed that they were practicing ancestral customs and rites that had been protected by a treaty signed in 1760 between the band and Brigadier-General James Murray, the Governor of the City and District of Quebec. The accused were convicted of the offences at trial and a subsequent appeal to the summary conviction appeal court was dismissed. A further appeal to the Quebec Court of Appeal was allowed and the charges were dismissed. The Quebec Court of Appeal's judgment

See Macklem, supra note 23 at 427; $R$. v. Johnston (1966), 56 D.L.R. (2d) 749 at 753 (Sask C.A.) where, in response to a Treaty No. 6 Indian's claim that the terms of the treaty provided him with general hospital services from the federal government, Culliton C.J. held that there was: "nothing historically, or in any dictionary definition, or in any legal pronouncement, that would justify the conclusion that the Indians, in seeking and accepting the Crown's obligation to provide a 'medicine chest' had in contemplation provision of all medical services, including hospital care."

Wildsmith, supra note 24 at 334. Note also ibid. at 326: "Though Sparrow's analysis in approaching s. 35 is no doubt important to a s. 35-treaty rights case as well, treaty rights ought, arguably, to be better protected than Aboriginal rights." In a footnote accompanying this latter statement, Wildsmith explains the basis for this assertion: "The basic point is that a deliberate breach of an explicit treaty promise is harder to reconcile with notion of honourable conduct and fiduciary obligations." 
was upheld by the Supreme Court of Canada. The Supreme Court determined that the Huron band had the right to practice its ancient customs and rites in the park. It held that the treaty's intent was to enable the band to exercise its customs and rites over the entirety of the territory the band had frequented, as long as their performance was not incompatible with the Crown's use of the territory. ${ }^{77}$

Once the treaty was determined to be valid - and thereby prevailed over the provincial parks legislation - the Supreme Court examined whether the treaty had either been extinguished prior to the date of the offences or whether the Huron band's non-use of the treaty rendered it null and void. The Crown argued that the treaty had been extinguished by either the Articles of Capitulation at Montreal, $1760,{ }^{78}$ the Treaty of Paris, $1763,{ }^{79}$ or the Royal Proclamation of $1763 .^{80}$ The Supreme Court determined that neither those documents nor the administrative history relied on by the Crown presented persuasive evidence that the 1760 treaty had been extinguished. Lamer J., as he then was, held that the Articles of Capitulation at Montreal, signed between Britain and France without the consent of the Huron band, could not extinguish the band's rights in the 1760 treaty. Since Indian treaties were solemn agreements between the Crown and Aboriginal peoples, he concluded that only the band could consent to the treaty's extinguishment. ${ }^{81}$

Lamer J. further found that to enable an agreement between Britain and France to extinguish the rights of the Hurons under a separate treaty "would be contrary to the general principles of law." ${ }^{382}$ He held that the same reasoning applied to the effects of the Treaty of Paris, 1763, which was also signed between Britain and France without involving the Hurons. Finally, Lamer J. dismissed the Crown's argument that the Royal Proclamation of 1763 extinguished the Huron band's rights under the treaty because it failed to confirm those rights. ${ }^{83}$ At the same time, he found that the rights conferred by the Proclamation did not extinguish any other right acknowledged or granted by the Crown under the terms of any treaty. ${ }^{84}$

In addition to finding that treaties signed between Britain and the Crown or declarations of British policy could not extinguish a treaty signed between the Crown and Aboriginal peoples, the Sioui decision also demonstrated that the non-invocation

Sioui, supra note 53 at 462.

78 The full name of this document is the Articles of Capitulation Between their Excellencies Major General Amherst, Commander in Chief of his Brittanic Majesty's troops and forces in North-America, on the one part, and the Marquis de Vaudreuil, \&c. Governor and Lieutenant-General for the King in Canada on the other, Montreal, 8 September 1760. The document is reproduced in A. Shortt \& A.G. Doughty, eds., Documents Relating to the Constitutional History of Canada, 1759-1791, Part I (Ottawa: King's Printer, 1918) at 33. See also NYCD, supra note 70 , vol. 10 at 1117 .

Under which France formally surrendered its remaining Canadian land possessions to Britain, save for the islands of St. Pierre and Miquelon.

R.S.C. 1985, App. II, No. 1.

Sioui, supra note 53 at 456.

Ibid.

Ibid. at 457.

Ibid. at 458. 
of a treaty for a considerable length of time, or at all, does not affect its legal nature or effectiveness. Treaty rights were held to accrue to the Aboriginal signatories to treaties by virtue of the agreements reached between them and the Crown, not whether those rights have or have not been asserted. As Lamer J. explained: "The fact that the document has allegedly not been used in the courts or other institutions of our society does not establish that it is not a treaty. Non-use may very well be explained by observance of the rights contained in the document or mere oversight." ${ }^{85}$ From the Sioui decision, it may be seen that an agreement between Aboriginal peoples and the Crown that demonstrates "the intention to create obligations, the presence of mutually binding obligations and a certain measure of solemnity" ${ }^{36}$ is a valid treaty at law by virtue of those circumstances being present.

The Sioui decision is important for its statements regarding the Crown's obligation to consult or involve Aboriginal peoples and to obtain their consent prior to being able to alter their rights under treaties. The Supreme Court explicitly recognized that treaties are not unilateral documents and, as such, the Crown may not alter or extinguish rights that it had agreed to protect within them without involving the Aboriginal signatories. As the court explained, "[t]he very definition of a treaty thus makes it impossible to avoid the conclusion that a treaty cannot be extinguished without the consent of the Indians concerned." ${ }^{87}$ From this statement, two things may be ascertained. Initially, it may be seen that treaties and the rights contained within them are, indeed, capable of being altered or extinguished. ${ }^{88}$ However, if treaties or treaty rights are to be altered or extinguished, that may only take place with the consent of the Aboriginal peoples concerned. In light of this statement, it would appear that where strict proof of the extinguishment of a treaty is provided, that would necessarily have to entail proof of the Aboriginal peoples' consent to that extinguishment. ${ }^{89}$ Simply demonstrating that contrary legislation had effectively nullified existing treaty rights or that the promulgation of legislation provided a "clear and plain" intent to extinguish those rights is, in light of the Sioui decision, insufficient, in the absence of a demonstrated indication of Aboriginal consent.

What occurred in Sioui was the balancing of the Lorette band's treaty rights with competing interests - namely the Crown's interests in the park and its regulation. While the treaty stated that the Huron tribe would be able to maintain the free exercise of their religion and customs, it did not provide a territorial limitation for the exercise of those rights..$^{90}$ Consequently, the Supreme Court held that the intention of the parties at the time the treaty was signed would provide the parameters for defining the

Ibid. at 454 . See also ibid. at $458-59$.

Ibid. at 441.

Ibid. at 456.

After the promulgation of s. 35(1) of the Constitution Act, 1982, treaties may no longer be unilaterally extinguished by the Crown.

Indeed, this is consistent with Aboriginal understandings of treaties as mutual compacts which required the consent of all parties prior to effectuating any changes in the agreements made: see D. N. Paul, We Were Not the Savages: A Micmac Perspective on the Collision of European and Aboriginal Civilizations (Halifax: Nimbus Publishing, 1993) at 69.

Sioui, supra note 53 at 432. 
rights' territorial restrictions. The court found that the treaty itself was an attempt to balance the Crown's rights with those of the Huron people. By failing to indicate the territorial scope of the treaty, the court surmised that the treaty was intended to reconcile the Crown's desire to expand its territorial acquisitions with the Hurons' endeavour to protect their customs and religion. Placing this compromise within the modern setting that led up to the charges being laid against the respondents resulted in a finding which allowed the Hurons to exercise their customs within all parts of their traditional territory where such exercise was not incompatible with the Crown's right of occupancy. ${ }^{91}$

The balancing of competing interests in Sioui is different than that imposed by the Supreme Court in Sparrow. Whereas the Sparrow test imposes procedural requirements that the Crown's legislative initiatives must pass to be valid restrictions upon the exercise of Aboriginal rights, the Sioui model represents an attempt at conciliation that is based upon the intentions of the parties at the time a treaty is signed. These intentions may be discovered through a contextual examination of the parties' goals and ambitions, their conduct previous to, during, and after the negotiation of the treaties, as well as what would be reasonable to conclude from the aforementioned, paying heed to the relative positions and strengths of the parties during the period in question. On this basis, the Sioui model is more consistent with the good faith observance of Aboriginal treaties in their negotiated form - as well as the negotiated form of treaty rights - than is the Sparrow test. Rather than looking at whether legislative infringements of rights are justifiable under the Sparrow test, the Sioui model adopts as its starting point the desire to find appropriate methods of maintaining the exercise of rights protected under the treaties in a manner that attempts to reconcile treaty intentions with contemporary realities.

\section{CONCLUSION}

Understanding the significant differences between Aboriginal and treaty rights requires that the regulation of those rights be viewed in a manner which recognizes their distinctiveness from one another. Since Aboriginal rights are not the same as treaty rights it would, prima facie, be inappropriate to propose using the same method for regulating each of them. Whereas the Sparrow justificatory test may be appropriate for the limitation of Aboriginal rights, it is suggested that the method of balancing treaty rights with the Crown's legislative desires in Sioui is a far more appropriate method of dealing with the limiting of treaty rights.

When treaties were signed between the Crown and Aboriginal nations, they were signed on the basis that the compacts made between them would be continuous and everlasting. Indeed, the lasting nature of treaties is indicated by the description of treaties continuing "as long as the sun rises over our head and as long as the water 
runs,"92 or being "inviolable \& lasting as the great lights of Heaven and the immoveable Mountains. ${ }^{.93}$ The Covenant Chain alliance, a military, political, social, and economic alliance initially between the Dutch and River Indians of the Hudson River region, but later forged between the British and Iroquois Confederacy and expanded to encompass a host of other Aboriginal nations, is a prime example of Crown-Native treaties as solemn, binding, and continuous agreements that were understood to be faithfully observed by all parties. ${ }^{94}$ The mutuality and solemnity of the Covenant Chain alliance is represented in the following exchange of promises between Sir William Johnson and the Six Nations on 20 February 1756:

\section{Brethren}

This animates me with fresh pleasure and affection, and at this important conjuncture of affairs to brighten and strengthen the Covenant Chain, that has so long linked us together in mutual friendship and brother[ly] affection which I hope will continue inviolable and sacred, as long as the Sun shines or the Rivers continue to water the earth, notwithstanding all the intrigues of our old and perfidious enemys, who have left no means unessayed, and especially at this time to weaken and divide us that so they may in the event root out the remembrance of your name, and Nations from the face of the earth.

\section{A large Covenant Belt.}

\section{Brother Warraghiyagey}

We have now opened our minds with Freedom \& sincerity and we understand each other clearly let us mutually remember our engagements which we have again so solemnly renewed and if at any time

Ojibway Chief Mawedopenais to Lieutenant-Governor Alexander Morris at the negotiations surrounding Treaty No. 3, in A. Morris, The Treaties of Canada With the Indians of Manitoba and the North-West Territories, Including the Negotiations on Which They Were Based (Toronto: Belfords, Clarke, 1880) at 73.

See also the promise made by Lieutenant-Governor Morris to Chief Mawedopenais at the signing of Treaty No. 3, ibid. at 75: "I accept your hand and with it the lands, and will keep all my promises, in the firm belief that the treaty now to be signed will bind the red man and the white together as friends for ever." From William Johnson's speech at Onondaga Lake, 26 June 1756, in NYCD, supra note 70, vol. 7 at 139.

94 See P.C. Williams, The Chain (LL.M. thesis, Osgoode Hall Law School, 1982) at 59 [unpublished]:

The most constant relationship, and the one that had the longest and widest effect, is that of the Covenant Chain of silver, binding the British colonies and the Indian nations together in friendship, peace and mutual assistance. It stretches from the east coast of North America to the west of Lake Superior, and from the coasts of James Bay to the Florida borders. The Chain, like the road, the pipe and the wall, is an enduring symbol of international relations in North America. 
our enemy should attack us, prove by your readiness to support \& assist us, that you really love us, and we assure you we shall not be wanting on our parts to give proofs of the like fidelity, \& friendship.

\section{A Belt."s}

The Covenant Chain alliance demonstrates the reciprocity with which treaties were negotiated. Treaties emerged as the result of negotiations between the parties, not out of unilateral action, paternalism, or the gratuitous benevolence of either side:

[T] he Aboriginal parties to treaties were considered to be distinch, self-governing nations, capable of making collective decisions, of establishing co-equal relationships ("alliances") and of controlling their own affairs. They had the capacity to negotiate with the Crown, and to voluntarily agree or withhold consent. The Crown approached the Aboriginal societies on the basis that problems were to be solved through co-operation, negotiation and quid pro quo bargaining, rather than unilateral imposition. ${ }^{\%}$

Since treaty rights stem from negotiated compacts that involved the consent and cooperation of the Crown and the Aboriginal parties to them, it would be unseemly to have them treated in the same fashion as Aboriginal rights, which arose under entirely different circumstances and did not involve the consent or cooperation of the Crown. As Wildsmith has noted:

\footnotetext{
The treaties were the product of consultation and negotiation and purported to be based on the co-operation and consent of the Aboriginal societies. They were intended to clarify aspects of the relationship between the Aboriginal societies and the Crown, but the treaties did not purport to deal with all aspects of the relationship between the parties. They as well do not purport to be imposed against the will of the Aboriginal nations. Aboriginal consent was necessary to form treaties; Aboriginal consent was necessary to terminate treaties. ${ }^{97}$
}

Had the Crown wanted to limit the rights of the Aboriginal peoples in treaties, it could have done so at the time that the treaties were signed. ${ }^{98}$ To sanction the notion of treaties as documents in which the Crown agreed to honour and respect enunciated rights only to ascribe to it the ability to unilaterally infringe upon those rights at a later date is repugnant to the solemnity of the treaties and brings dishonour to the Crown. Recent Aboriginal rights jurisprudence in Canada has recognized that the honour of the Crown in dealings with the Aboriginal peoples has not always been upheld. As the Supreme Court of Canada noted in Sparrow, "there can be no doubt that over the years

\% Wildsmith, supra note 24 at 331 . See also ibid. at 330; M. Jackson, "The Articulation of Native Rights in Canadian Law" (1984), 18 U.B.C. L. Rev. 255 at 257; Sioui, supra note 53 at 437, 448. Wildsmith, supra note 24 at 331 .

93 Note the similar statement made in Leech Lake Band of Chippewa Indians v. Herbst, 334 F. Supp. 1001 (D. Minn. 1971) at 1005 concerning the status of the band's reservation: "If it was the intention of Congress to disestablish the Leech Lake Reservation, the Congress knew how to say so in clear language." 
the rights of the Indians were often honoured in the breach." 99 In seeking to rectify the mistakes of the past, modern courts have emphasized the importance of upholding the honour of the Crown in its dealings with the Aboriginal peoples. ${ }^{100}$ However, in many instances, Canadian courts have upheld the Crown's ability to unilaterally infringe upon treaty right guarantees.

In $R$ v. Sikyea it was held that the guarantee of hunting rights in Treaty No. 11 was abrogated by the terms of the Migratory Birds Convention, $1916^{101}$ by which the Crown restricted the hunting of migratory birds. As Johnson J.A. explained:

It is always to be kept in mind that the Indians surrendered their rights in the territory in exchange for these promises. This "promise and agreement", like any other, can, of course, be breached, and there is no law of which I am aware that would prevent Parliament by legislation, properly within 5.91 of the B.N.A. Acl, from doing so. ${ }^{102}$

What should be noted, however, was that Treaty No. 11 provided that the Aboriginal signatories "shall have the right to pursue their usual vocations of hunting, trapping, and fishing throughout the tract surrendered as heretofore described." Moreover, the Treaty No. 11 commissioners reported that they had assured the Aboriginals that their ability to hunt, trap, and fish would be unaffected by signing the treaty:

The Indians seemed afraid, for one thing, that their liberty to hunt, trap and fish would be taken away or curtailed, but were assured by me that this would not be the case ... and, in fact, that more twine for nets and more ammunition were given under the terms of this treaty than under any of the preceding ones; this went a long way to calm their fears. ${ }^{103}$

As Johnson J.A. stated in his judgment in Sikyea, "there is nothing in this [Treaty No. 11 commissioners'] report which would indicate that the Indians were told that their right to shoot migratory birds had already been taken away from them." ${ }^{104}$ Although

Supra note 1 at 404 . See also the statement by the Royal Commission on Aboriginal Peoples in Partners in Confederation, supra note 49 at 26: "The treaties were honoured by Canadian governments as much in the breach as in the observance." See, for example, $R$. v. Taylor and Williams (1981), 62 C.C.C. (2d) 227 at 235 (Ont. C.A.); Sparrow, supra note 1 at 408 ; Badger, supra note 4 at 92 (para. 41).

101 Specifically the sanction, ratification, and confirmation of the Convention by Canada via the Migratory Birds Convention Act, 1917 (Can.), c. 8 and, later the Convention's implementation in Canadian law through the Migratory Birds Convention Act, R.S.C. 1952, c. 179.

$R$ v. Sikyea (1964), 43 D.L.R. (2d) 150 at 154 (N.W.T.C.A.). Of course, Johnson J.A.'s statement in Sikyea is now subject to the constitutional protection of treaty rights and the justificatory test for the abrogation of those rights instituted by the Supreme Court of Canada's decision in Sparrow, supra note 1 . lbid. at 158.

Ibid. at 159. Note also the statement made by Morrow J. in Re Paulette and Registrar of Titles (No. 2) (1973), 42 D.L.R. (3d) 8 at 33 (N.W.T.S.C.) conceming representations made regarding Treaties 8 and 11:

Throughout the hearings before me there was a common thread in the testimony - that the Indians were repeatedly assured they were not to be deprived of their hunting, fishing and trapping rights. To me, hearing the witnesses at first hand ... many of whom were there at the signing, some of them having been directly involved in the treaty making, it is almost 
the Migratory Birds Convention was implemented into Canadian law prior to the signing of Treaty No. 11, the assurances to the Aboriginals provided by the treaty commissioners mitigate against concluding that the Crown could ignore the promises it made to the Aboriginals under Treaty No. 11 because of the conflict with the Migratory Birds Convention Act.

Later, in $R$. v. Horseman, the Supreme Court of Canada held that the unilateral imposition of the Natural Resource Transfer Agreements, 1930 ("NRTA") ${ }^{105}$ extinguished the commercial right to hunt under Treaty No. 8. ${ }^{106}$ While the Supreme Court unanimously agreed that Treaty No. 8 contained a commercial right of hunting, the majority held that the combined effects of the Alberta NRTA and the Alberta Wildlife $A c t^{107}$ eliminated that right. In accordance with the precedents established in Frank v. The Queen, ${ }^{108}$ R. v. Sutherland Wilson and Wilson, ${ }^{109}$ and $R$. v. Moosehunter, ${ }^{110}$ the majority held that the NRTA "merged and consolidated" existing treaty rights into a uniform set of hunting and fishing rights for all treaty Aboriginal nations in Manitoba, Saskatchewan, and Alberta. ${ }^{\prime \prime \prime}$

Although Cory J.'s majority judgment conceded that "it might be politically and morally unacceptable in today's climate to take such a step as that set out in the 1930 agreement without consultation with and concurrence of the native peoples affected," he nevertheless determined that "the power of the federal government to unilaterally make such a modification is unquestioned and has not been challenged in this case."112 He buttressed this conclusion, in part, by noting that Treaty No. 8 expressly limited its hunting and fishing guarantees by rendering them "subject to such regulations as may from time to time be made by the Government of the country."113

As had been the situation in Sikyea, the majority's decision in Horseman did not tell the entire story. The Treaty No. 8 commissioners' report, like the report of the commissioners to Treaty No. 11 assured the Aboriginal signatories that their rights would remain unaffected by the treaty:

unbelievable that the Government party could have ever returned from their efforts with any impression but that they had given an assurance in perpetuity to the Indians in the territories that their traditional use of the lands was not affected.

See S.C. 1930 , c. 29 , s. 11 ; S.C. 1930 , c. 41 , s. 10 ; and S.C. 1930 , c. 3, s. 10 , which were incorporated into the Constitution $A c t, 1930$ (U.K.), 20-21 Geo. V., c. 26. While the abbreviation used is singular, any subsequent references to "NRTA" are to be read to apply equally to each of the three transfer agreements. Where reference is intended to be made to only one of the transfer agreements, that distinction is made in the text.

Horseman, supra note 68.

R.S.A. 1980 , c. W-9.

(1977), 75 D.L.R. (3d) 481 (S.C.C.).

(1980), 113 D.L.R. (3d) 374 (S.C.C.).

(1981), 123 D.L.R. (3d) 95 (S.C.C.).

Horseman, supra note 68 at 932-33.

lbid. at 934.

lbid. at 934-35. Indeed, this boilerplate phrase was used extensively in Aboriginal treaties in relation to hunting and fishing rights. 
Our chief difficulty was the apprehension that the hunting and fishing privileges were to be curtailed. The provision in the treaty under which ammunition and twine is to be furnished went far in the direction of quieting the fears of the Indians, for they admitted that it would be unreasonable to furnish the means of hunting and fishing if laws were to be enacted which would make hunting and fishing so restricted as to render it impossible to make a livelihood by such pursuits. But over and above the provision, we had to solemnly assure them that only such laws as to hunting as were in the interest of the Indians and were found necessary in order 10 protect the fish and fur-bearing animals would be made, and that they would be free to hunt and fish after the treaty as they would be if they never entered into it. ${ }^{114}$

Wilson J.'s analysis of the historical context of Treaty No. 8 in her dissenting judgment in Horseman led her to conclude that the treaty was a solemn engagement that promised the Aboriginal signatories that they would continue to have unlimited access to wildlife. She found that the sole basis for the Aboriginal peoples signing the treaty was the Crown's promise that their rights would be protected. ${ }^{115}$ Furthermore, unlike the Sikyea situation, the NRTA came into effect quite some time after Treaty No. 8 was signed.

The Supreme Court's judgment in Horseman was recently considered in that same court's treatment of the Badger case, which also involved the conflict between Treaty No. 8 rights to hunt, the Alberta NRTA, and the Alberta Wildlife Act. ${ }^{116}$ The primary judgment in Badger, like Horseman, was rendered by Cory J. It agreed with Horseman's finding that the hunting rights under Treaty No. 8 had been merged and consolidated by the NRTA. However, in Badger, Cory J. found that the NRTA did not extinguish or replace the hunting rights guaranteed under Treaty No. 8, but merely modified those rights where they came into conflict with the NRTA. As he explained:

[T] promises and the Crown's honour requires the Court to assume that the Crown intended to fulfil its promises. Treaty rights can only be amended where it is clear that effect was intended.... [T] he Treaty No. 8 right to hunt has only been altered or modified by the NRTA to the extent that the NRTA evinces a clear intention to effect such a modification.... Unless there is a direct conflict between the NRTA and a treaty, the NRTA will not have modified the treaty rights. ${ }^{117}$

Canadian courts have been firm in their findings that the Crown may breach its promises made to the Aboriginal peoples in treaties through the exercise of its s. 91(24) powers. ${ }^{118}$ However, on more than one occasion, the courts have been disdainful of this fact. ${ }^{119}$ On other occasions, the courts have expressed remorse or frustration over

Ibid. at 910 [emphasis added]. See also the references cited by Wilson J., ibid. at 910-11.

Ibid. at 911-12. See the similar sentiment expressed in Badger, supra note 4 at 91 (para. 39).

Supra note 107.

Badger, supra note 4 at 94 (para. 47).

Note, most recently, Badger, supra note 4 at 105 (para. 74).

See, for example, the dissenting judgment of Cartwright J. in R. v. George (1966), 55 D.L.R. (2d)

386 at 396-97 (S.C.C.):

We should, I think, endeavour to construe the treaty of 1827 and those Acts of Parliament which bear upon the question before us in such manner that the honour of the Sovereign 
the Crown's use of its s. 91(24) powers in contravention of its treaty obligations, as indicated in the commentary by Johnson J.A. in Sikyea:

It is, I think, clear that the rights given to the Indians by their treaties as they apply to migratory birds have been taken away by this Act and its Regulations. How are we to explain this apparent breach of faith on the part of the Government, for I cannot think it can be described in any other terms? This cannot be described as a minor or insignificant curtailment of these treaty rights, for game birds have always been a most plentiful, a most reliable and a readily obtainable food in large areas of Canada. I cannot believe that the Government of Canada realized that in implementing the Convention they were at the same time breaching the treaties that they had made with the Indians. It is much more likely that these obligations under the treaties were overlooked - a case of the left hand having forgotten what the right hand had done. ${ }^{120}$

\section{Indeed, immediately after making the above statement, Johnson J.A. noted that:}

The subsequent history of the Government's dealing with the Indians would seem to bear this out. When the treaty we are concerned with here was signed in 1921, only five years after the enactment of the Migratory Birds Convention Act, we find the Commissioners who negotiated the treaty reporting:

The Indians seemed afraid, for one thing, that their liberty to hunt, trap and fish would be taken away or curtailed, but were assured by me that this would not be the case, and the Government will expect them to support themselves in their own way, and, in fact, that more twine for nets and more ammunition were given under the terms of this treaty

may be upheld and Parliament not made subject to the reproach of having taken away by unilateral action and without consideration the rights solemnly assured to the Indians and their posterity by treaty.

See also $R$ v. Daniels (1968), 2 D.L.R. (3d) 1 at 13-14 (S.C.C.) per Hall J., dissenting: "The lamentable history of Canada's dealings with Indians in disregard of treaties made with them ... ought in justice to allow the Indians to get the benefit of an unambiguous law which for once appears to give them what the treaties and the Commissioners who were sent to negotiate those treaties promised."

Sikyea, supra note 102 at 158 . See also Wesley, supra note 67 at $788,789,790$ :

Assuming as 1 do that our treaties with Indians are on no higher plane than other formal agreements yet this in no wise makes it less the duty and obligation of the Crown to carry out the promises contained in those treaties with the exactness which honour and good conscience dictate and it is not to be thought that the Crown has departed from those equitable principles which the Senate and the House of Commons declared in addressing Her Majesty in 1867, uniformly govemed the British Crown in its dealings with the aborigines.

It is true that Government regulations in respect of hunting are contemplated in the Treaty but considering the Treaty in its proper setting I do not think that any of the makers of it could by any stretch of the imagination be deemed to have contemplated a day when the Indians would be deprived of an unfettered right to hunt game of all kinds for food on unoccupied Crown land.

It is satisfactory to be able to come to this conclusion and not to have to decide that "the Queen's promises" have not been fulfilled. It is satisfactory to think that legislators have not so enacted but that the Indians may still be "convinced of our justice and determined resolution to remove all reasonable cause of discontent." 
than under any of the preceding ones; this went a long way to calm their fears. I also pointed out that any game laws made were to their advantage, and, whether, they took treaty or not, they were subject to the laws of the Dominion.

and there is nothing in this report which would indicate that the Indians were told that their right to shoot migratory birds had already been taken away from them. ${ }^{121}$

Absolving the Crown of its failure to live up to its treaty promises runs contrary to the notion of treaties being "inviolable \& lasting as the great lights of Heaven and the immoveable Mountains." Furthermore, the notion of maintaining the honour of the Crown in its dealings with Aboriginal peoples is offended by finding that Crown legislation such as the Migratory Birds Convention Act or the NRTA may, unilaterally and without consultation or consent, override or alter the nature of solemn treaty rights. This was recognized by the additional reasons provided by Kerans J.A. in the Alberta Court of Appeal's disposition of Badger:

I find the approach taken by the majority in Horseman about the effect of the Constitution Act, 1930 upon treaty rights deeply troubling.... My concern is that whatever happened in 1930 happened without the participation of one party to the Treaty. The Aboriginal Canadians were not invited to participate in the negotiations leading to the 1930 agreements.... I incline to the view that they did not believe they were changing any native rights. I fear the notion of "merger and consolidation" is the result of a patina applied by a later generation of judicial interpretation. That is the reason for my disquiet, and for these additional reasons. ${ }^{122}$

With the passage of the Constitution Act, 1982 and its protection of treaty rights in s. 35(1), treaty rights may no longer be treated as moral obligations subject to abrogation at will by the Crown. Section 35(1) acts as a check upon the federal Crown's unfettered legislative power over "Indians, and Lands reserved for the Indians" under s. 91(24) of the Constitution Act, 1867. It shapes and informs the use of those powers to ensure that they are consistent with the protection of treaty rights, the honour of the Crown, and its fiduciary obligations to Aboriginal peoples. As the Supreme Court of Canada explained in Sparrow:

There is no explicit language in the provision that authorizes this court or any court to assess the legitimacy of any government legislation that restricts Aboriginal rights. Yet, we find the words "recognition and affirmation" incorporate the fiduciary relationship referred to earlier and so import some restraint on the exercise of sovereign power. Rights that are recognized and affirmed are not absolute. Federal legislative powers continue, including, of course, the right to legislate with respect to Indians pursuant to s. 91(24) of the Constitution Act, 1867. These powers must, however, now be read together with s. 35(1). In other words, federal power must be reconciled with federal duty and the best way to achieve that reconciliation is to demand the justification of any governmental regulation that infringes upon or denies Aboriginal rights. ${ }^{123}$ 
Interestingly, the Sioui decision, like the vast majority of treaty cases decided by the Supreme Court of Canada to this point, was not concerned with the application of s. 35(1). Therefore, it is unclear how Sioui's requirement of Aboriginal consent to the extinguishment of treaties or treaty rights meshes with s. 35(1)'s protection of existing treaty rights. This issue was not addressed by the Supreme Court in either Badger or Coté. While s. 35(1) only protects treaty rights in existence on 17 April 1982, if the consent of Aboriginal peoples is necessary for extinguishment, that would appear to indicate that those treaties which the Crown purportedly extinguished through other means were not validly extinguished and therefore should be protected under s. 35(1). For instance, the myriad of cases in which treaty rights were held to be abrogated or extinguished by contrary legislation or other unilateral enactments of the Crown, such as Sikyea, Horseman, and Badger, would not satisfy the requirements for extinguishment mandated by Sioui. How this discrepancy will be played out in the jurisprudence remains to be seen.

As the discussion of Aboriginal treaties and treaty rights herein has attempted to illustrate, treaties are foundational documents in the history and development of the Canadian state. These compacts between the Crown and Aboriginal nations were vital to Britain's conquest of New France and its resistance of American territorial expansion in what is now Canada. Later, they were instrumental in the expansion of the nation. The constitutional entrenchment of Aboriginal treaties and the protection imparted to the rights contained within them ought to be viewed as a recognition of their critical role in the development of Canada and continuing importance to the Canadian fabric. To enable s. 35(1) to perform the protective function intended of it, the rights which are encompassed within its general protection must be more clearly understood. What is required, then, is a greater understanding of what is encompassed within s. 35(1), beginning with the distinction between Aboriginal rights and treaty rights. A major inroad into establishing this distinction may be achieved by putting an end to the application of the Sparrow justificatory test to treaty rights in favour of the approach suggested in Sioui.

The Sioui model of requiring Aboriginal consent to the limiting of treaty rights has been suggested to be a preferable method of addressing the limitation of treaty rights than the Sparrow justificatory test because of the unique nature of Indian treaties and the rights contained within them. While it does not provide a definitive test in the manner that Sparrow did, it provides a more appropriate framework for considering treaty rights that befits their separate status from Aboriginal rights. This article has attempted to demonstrate that treaty rights are not the same as Aboriginal rights and, therefore, ought not be treated in an identical manner. This point becomes more poignant when, as in Coté, the method of justifying legislative initiatives that seek to infringe upon treaty rights fails to account for the status of those rights as products of bargains between Aboriginal peoples and the Crown. 